\title{
RATE AT WHICH MUSCLE BECOMES JOINED TO SCLERA AFTER OPERATIONS OF RECESSION AND RESECTION*
}

\author{
BY \\ R. M. INGRAM \\ University Departments of Ophthalmology and Pathology, Manchester
}

\begin{abstract}
"The major contributions of surgical interest which have been made to our understanding of wound healing since Virchow and Paget rest with quantifying the rate of repair and the appraisal of factors which affect it." (Dunphy, 1960.)
\end{abstract}

Although a great deal of work has been carried out in investigations of the rate at which wounds heal, the only ocular wound that has been studied from this aspect is the cataract wound (Gliedman and Karlson, 1955). This paper reports an investigation into the rate at which the rabbit extra-ocular muscle becomes re-attached to the sclera after the operations of recession and resection.

Carrel (1910) first studied the rate at which an open skin-wound healed. Incisional wounds were not studied until the classic work of Howes and Harvey (1929), who thought that the best way to measure the rate of deposition of fibrous tissue in these wounds was to record their tensile strength at intervals after operation. They argued that as the catgut sutures lost their strength after three or four days in the tissues, the strength of the wound after this time was almost entirely due to the fibrous tissue deposited. Studying the rate of healing of stomach wounds they found that their results could be represented on a graph, as shown in Fig. 1. The validity of the general shape of this curve was confirmed by histological studies of the rate of deposition of fibrous tissue (Howes, 1933; Whipple, 1933; Hess, 1953). These wounds involved the union of muscle to muscle and they attained normal strength within 14 days of operation. However, this was not the case where fibrous tissue became reunited with fibrous tissue (Mason and Allen, 1941; Douglas, 1952), since three months after operation such wounds are not more than 40 per

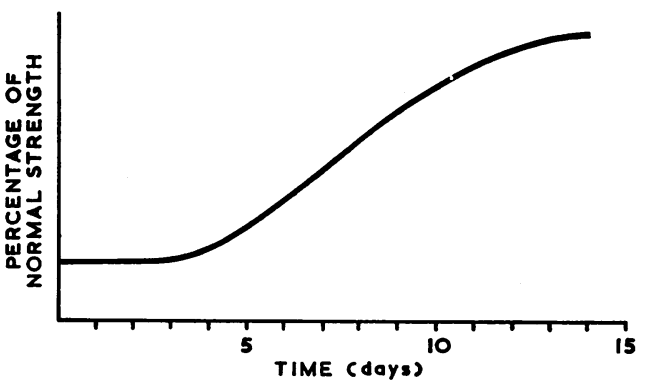

Fig. 1.-Graph representing the increase in the tensile strength of wounds at intervals after operation. (Howes and Harvey, 1929.) cent. of their normal strength. The slow increase in strength of the cataract wound is an example of this (Gliedman and Karlson, 1955). In the present work the rate of healing of muscle to fibrous tissue is studied for the first time. 
TENSILE STRENGTH OF RECESSION AND RESECTION WOUNDS SUTURED WITH 3/0 CATGUT

\begin{tabular}{|c|c|c|c|c|c|c|c|c|c|c|}
\hline \multicolumn{6}{|c|}{ Recession Wound } & \multicolumn{5}{|c|}{ Resection Wound } \\
\hline $\begin{array}{c}\text { No. of } \\
\text { Days } \\
\text { after } \\
\text { Operation }\end{array}$ & $\begin{array}{l}\text { No. of } \\
\text { Rabbit }\end{array}$ & $\begin{array}{l}\text { Weight } \\
\text { of } \\
\text { Rabbit } \\
\text { in } g .\end{array}$ & $\begin{array}{c}\text { Tensile } \\
\text { Strength } \\
\text { of Wound } \\
\text { in lb. }\end{array}$ & $\begin{array}{c}\text { Mean } \\
\text { Tensile } \\
\text { Strength } \\
\text { of Wound }\end{array}$ & \begin{tabular}{|c|} 
Standard \\
Deviation \\
of \\
Mean
\end{tabular} & \begin{tabular}{|c|} 
No. of \\
Days \\
after \\
Operation
\end{tabular} & $\begin{array}{l}\text { No. of } \\
\text { Rabbit }\end{array}$ & $\begin{array}{c}\text { Tensile } \\
\text { Strength } \\
\text { of Wound } \\
\text { in } \mathrm{lb} \text {. }\end{array}$ & $\begin{array}{c}\text { Mean } \\
\text { Tensile } \\
\text { Strength } \\
\text { of Wound }\end{array}$ & $\begin{array}{c}\text { Standard } \\
\text { Deviation } \\
\text { of } \\
\text { Mean }\end{array}$ \\
\hline 0 & $\begin{array}{r}5 \\
49 \\
62 \\
93 \\
94 \\
95\end{array}$ & $\begin{array}{l}2,440 \\
2,900 \\
2,650 \\
2,140 \\
2,200 \\
2,000\end{array}$ & $\begin{array}{l}0.52 \\
0.58 \\
0.61 \\
0.75 \\
0.64 \\
0.69\end{array}$ & 0.632 & 0.085 & $\mathbf{0}$ & $\begin{array}{r}5 \\
49 \\
62 \\
93 \\
94 \\
95\end{array}$ & $\begin{array}{l}D^{*} \\
0.65 \\
0.15 \\
0.36 \\
0.37 \\
0.26\end{array}$ & 0.358 & 0.231 \\
\hline 1 & $\begin{array}{l}26 \\
27 \\
28 \\
59 \\
74 \\
75\end{array}$ & $\begin{array}{l}3,000 \\
2,200 \\
2,250 \\
2,350 \\
2,360 \\
2,700\end{array}$ & $\begin{array}{c}1 \cdot 21 \\
0.97 \\
D^{*} \\
0.34 \\
0.60 \\
0.51\end{array}$ & $0 \cdot 726$ & 0.442 & 1 & $\begin{array}{l}26 \\
27 \\
28 \\
59 \\
74 \\
75\end{array}$ & $\begin{array}{l}0.67 \\
0.45 \\
0.82 \\
0.67 \\
0.40 \\
0.32\end{array}$ & 0.555 & $0 \cdot 203$ \\
\hline 2 & $\begin{array}{l}22 \\
23 \\
65 \\
66 \\
67\end{array}$ & $\begin{array}{l}2,550 \\
2,900 \\
2,650 \\
3,150 \\
2,800\end{array}$ & $\begin{array}{l}0.18 \\
0.55 \\
0.80 \\
0.50 \\
0.40\end{array}$ & 0.486 & $0 \cdot 281$ & 2 & $\begin{array}{l}22 \\
23 \\
65 \\
66 \\
67\end{array}$ & $\begin{array}{l}0.52 \\
0.61 \\
0.55 \dagger \\
0.48 \dagger \\
0.40 \dagger\end{array}$ & 0.512 & 0.097 \\
\hline 3 & $\begin{array}{l}24 \\
25 \\
79 \\
80 \\
81\end{array}$ & $\begin{array}{l}3,200 \\
3,000 \\
2,860 \\
2,330 \\
2,960\end{array}$ & $\begin{array}{l}0.74 \\
0.50 \\
0.45 \\
0.55 \\
0.48\end{array}$ & 0.544 & $0 \cdot 145$ & 3 & $\begin{array}{l}24 \\
25 \\
79 \\
80 \\
81\end{array}$ & $\begin{array}{l}0.96 \\
0.52 \\
0.45 \\
0.65 \dagger \\
0.33\end{array}$ & 0.582 & $0 \cdot 300$ \\
\hline 4 & $\begin{array}{l}39 \\
40 \\
47 \\
48 \\
60 \\
61\end{array}$ & $\begin{array}{l}2,800 \\
3,500 \\
2,600 \\
2,300 \\
2,800 \\
2,700\end{array}$ & $\begin{array}{l}0.79 \\
0.59+ \\
0.38 \\
0.54 \\
1.08 \\
0.74\end{array}$ & 0.687 & 0.254 & 4 & $\begin{array}{l}39 \\
40 \\
47 \\
48 \\
60 \\
61\end{array}$ & $\begin{array}{c}0.30 \\
D * \\
0.74 \\
0.61 \\
0.69 \\
0.49\end{array}$ & 0.566 & $0 \cdot 220$ \\
\hline 5 & $\begin{array}{l}14 \\
15 \\
16 \\
17 \\
18\end{array}$ & $\begin{array}{l}3,650 \\
2,650 \\
3,100 \\
2,800 \\
2,600\end{array}$ & $\begin{array}{l}0.96 \\
0.41 \\
0.98 \\
0.46 \\
0.88\end{array}$ & 0.738 & $0 \cdot 348$ & 5 & $\begin{array}{l}14 \\
15 \\
16 \\
17 \\
18\end{array}$ & $\begin{array}{l}0.95 \\
0.40 \\
1.03 \\
0.38 \\
0.51\end{array}$ & 0.652 & $0 \cdot 384$ \\
\hline 7 & $\begin{array}{r}1 \\
2 \\
6 \\
41 \\
42\end{array}$ & $\begin{array}{l}2,600 \\
2,600 \\
2,070 \\
3,700 \\
3,900\end{array}$ & $\begin{array}{l}0.68 \\
0.61 \\
0.60 \\
1.16 \\
0.78\end{array}$ & 0.766 & 0.289 & 7 & $\begin{array}{r}1 \\
2 \\
6 \\
41 \\
42\end{array}$ & $\begin{array}{l}0.63 \\
0.59 \\
0.84 \\
0.86 \\
0.79\end{array}$ & 0.742 & $0 \cdot 153$ \\
\hline 10 & $\begin{array}{l}55 \\
56 \\
96 \\
97 \\
99\end{array}$ & $\begin{array}{l}2,850 \\
2,750 \\
2,300 \\
2,300 \\
2,830\end{array}$ & $\begin{array}{l}0.77 \\
0.75 \\
0.66 \\
0.82 \\
1.09\end{array}$ & 0.818 & 0.203 & 10 & $\begin{array}{l}55 \\
56 \\
96 \\
97 \\
99\end{array}$ & $\begin{array}{l}0.63 \\
0.63 \\
1.04 \\
0.92 \\
1.16\end{array}$ & 0.876 & $0 \cdot 297$ \\
\hline 14 & $\begin{array}{l}43 \\
44 \\
45 \\
46 \\
51\end{array}$ & $\begin{array}{l}2,500 \\
2,450 \\
3,100 \\
3,100 \\
3,300\end{array}$ & $\begin{array}{l}1 \cdot 58 \\
0.60 \\
0.90 \\
0.74 \\
1.28\end{array}$ & 1.020 & 0.500 & 14 & $\begin{array}{l}43 \\
44 \\
45 \\
46 \\
51\end{array}$ & $\begin{array}{l}1 \cdot 70 \\
0 \cdot 52 \dagger \\
0 \cdot 84 \\
0.79 \\
0.83\end{array}$ & 0.936 & 0.556 \\
\hline 21 & $\begin{array}{r}4 \\
8 \\
13 \\
71 \\
72 \\
73\end{array}$ & $\begin{array}{l}2,350 \\
3,050 \\
2,700 \\
2,600 \\
2,220 \\
2,300\end{array}$ & $\begin{array}{l}D^{*} \\
1.08 \\
1 \cdot 11 \\
0.70 \\
0.94 \dagger \\
0.71\end{array}$ & 0.908 & 0.245 & 21 & $\begin{array}{r}4 \\
8 \\
8 \\
13 \\
71 \\
72 \\
73\end{array}$ & $\begin{array}{c}1 \cdot 18 \\
1.25 \\
0.86 \\
0.62 \\
0.74 \\
D^{*}\end{array}$ & 0.930 & 0.342 \\
\hline 28 & $\begin{array}{r}7 \\
83 \\
84 \\
85 \\
86 \\
87\end{array}$ & $\begin{array}{l}3,000 \\
4,100 \\
2,880 \\
2,470 \\
2,820 \\
2,350\end{array}$ & $\begin{array}{l}D^{*} \\
0.90 \\
1.34 \\
1.52 \\
1.16 \dagger \\
0.90 \dagger\end{array}$ & $1 \cdot 164$ & 0.339 & 28 & $\begin{array}{l}7 \\
83 \\
84 \\
85 \\
86 \\
87\end{array}$ & $\begin{array}{l}0.88 \\
0.78 \\
1.18 \\
1.10 \\
1.10 \\
0.76\end{array}$ & 0.967 & $0 \cdot 190$ \\
\hline 56 & $\begin{array}{r}9 \\
10 \\
29 \\
30 \\
33\end{array}$ & $\begin{array}{l}2,600 \\
2,350 \\
3,900 \\
2,400 \\
3,050\end{array}$ & $\begin{array}{l}0.80 \\
0 \cdot 71 \\
0.90 \dagger \\
0.83 \dagger \\
0.82\end{array}$ & 0.812 & 0.086 & 56 & $\begin{array}{r}9 \\
10 \\
29 \\
30 \\
33\end{array}$ & $\begin{array}{l}1.06 \\
0.96 \\
1.18 \\
1.22 \\
1.37\end{array}$ & $1 \cdot 158$ & $0 \cdot 195$ \\
\hline 84 & $\begin{array}{l}11 \\
12 \\
19 \\
20 \\
21\end{array}$ & $\begin{array}{l}2,500 \\
2,400 \\
3,550 \\
3,400 \\
3,500 \\
\end{array}$ & $\begin{array}{l}1.01 \\
0.64 \\
0.96 \dagger \\
0.72 \dagger \\
0.66\end{array}$ & 0.798 & $0 \cdot 217$ & 84 & $\begin{array}{l}11 \\
12 \\
19 \\
20 \\
21\end{array}$ & $\begin{array}{l}0.90 \\
1.29 \\
1.18 \\
1.80 \\
1.44\end{array}$ & $1 \cdot 322$ & 0.414 \\
\hline
\end{tabular}

\footnotetext{
* Result discarded on the grounds explained in the text. † Result allowed after the specimen had slipped out of one of the grips.
} 
TENSILE STRENGTH OF RECESSION AND RESECTION WOUNDS SUTURED WITH 2/0 SILK

\begin{tabular}{|c|c|c|c|c|c|c|c|c|c|c|}
\hline \multicolumn{6}{|c|}{ Recession Wound } & \multicolumn{5}{|c|}{ Resection Wound } \\
\hline $\begin{array}{c}\text { No. of } \\
\text { Days } \\
\text { after } \\
\text { Operation }\end{array}$ & $\begin{array}{l}\text { No. of } \\
\text { Rabbit }\end{array}$ & $\begin{array}{c}\text { Weight } \\
\text { of } \\
\text { Rabbit } \\
\text { in } \mathbf{g} .\end{array}$ & $\begin{array}{c}\text { Tensile } \\
\text { Strength } \\
\text { of Wound } \\
\text { in lb. }\end{array}$ & $\begin{array}{c}\text { Mean } \\
\text { Tensile } \\
\text { Strength } \\
\text { of Wound }\end{array}$ & $\begin{array}{c}\text { Standard } \\
\text { Deviation } \\
\text { of } \\
\text { Mean }\end{array}$ & $\begin{array}{c}\text { No. of } \\
\text { Days } \\
\text { after } \\
\text { Operation }\end{array}$ & $\begin{array}{l}\text { No. of } \\
\text { Rabbit }\end{array}$ & $\begin{array}{c}\text { Tensile } \\
\text { Strength } \\
\text { of Wound } \\
\text { in lb. }\end{array}$ & $\begin{array}{c}\text { Mean } \\
\text { Tensile } \\
\text { Strength } \\
\text { of Wound }\end{array}$ & $\begin{array}{c}\text { Standard } \\
\text { Deviation } \\
\text { of } \\
\text { Mean }\end{array}$ \\
\hline 0 & $\begin{array}{l}150 \\
151 \\
152 \\
159 \\
160 \\
197\end{array}$ & $\begin{array}{l}2,880 \\
2,680 \\
2,830 \\
3,000 \\
2,690 \\
2,500\end{array}$ & $\begin{array}{l}0.76 \\
0.18 \\
0.53 \\
0.56 \\
0.64 \\
0.44\end{array}$ & 0.518 & $0 \cdot 208$ & 0 & $\begin{array}{l}150 \\
151 \\
152 \\
159 \\
160 \\
197\end{array}$ & $\begin{array}{l}0.73 \\
0.48 \\
0.70 \\
D * \\
0.36 \\
0.45\end{array}$ & $0 \cdot 544$ & $0 \cdot 203$ \\
\hline 1 & $\begin{array}{l}170 \\
176 \\
177 \\
178 \\
179\end{array}$ & $\begin{array}{l}2,260 \\
3,040 \\
2,480 \\
2,850 \\
2,460\end{array}$ & $\begin{array}{l}0.43 \\
0.45 \\
0.51 \\
0.43 \\
0.42\end{array}$ & 0.448 & 0.044 & 1 & $\begin{array}{l}175 \\
176 \\
177 \\
178 \\
179\end{array}$ & $\begin{array}{l}0.40 \\
0.39 \\
0.55 \\
0.52 \\
0.42\end{array}$ & 0.456 & 0.092 \\
\hline 2 & $\begin{array}{l}181 \\
182 \\
183 \\
184 \\
185\end{array}$ & $\begin{array}{l}3,010 \\
2,750 \\
2,760 \\
2,140 \\
2,500\end{array}$ & $\begin{array}{l}0.78 \\
0.41 \dagger \\
0.65 \\
0.76 \\
0.40\end{array}$ & 0.600 & $0 \cdot 231$ & 2 & $\begin{array}{l}181 \\
182 \\
183 \\
184 \\
185\end{array}$ & $\begin{array}{l}0.38 \\
0.40 \\
0.66 \\
0.63 \\
0.43\end{array}$ & $0 \cdot 500$ & $0 \cdot 167$ \\
\hline 3 & $\begin{array}{l}158 \\
165 \\
166 \\
167 \\
168 \\
174\end{array}$ & $\begin{array}{l}2,840 \\
2,400 \\
2,670 \\
2,830 \\
2,340 \\
2,590\end{array}$ & $\begin{array}{c}0.40 \\
0.48 \\
0.65 \\
0.69 \\
D^{*} \\
0.49\end{array}$ & 0.542 & 0.153 & 3 & $\begin{array}{l}158 \\
165 \\
166 \\
167 \\
168 \\
174\end{array}$ & $\begin{array}{l}D^{*} \\
0 \cdot 47 \\
1 \cdot 25 \\
0 \cdot 80 \dagger \\
0 \cdot 70 \\
0 \cdot 59\end{array}$ & 0.762 & 0.373 \\
\hline 4 & $\begin{array}{l}169 \\
170 \\
171 \\
172 \\
173 \\
194\end{array}$ & $\begin{array}{l}2,370 \\
2,740 \\
2,530 \\
2,870 \\
2,210 \\
2,760\end{array}$ & $\begin{array}{l}0.82 \\
0.82 \\
0.79 \\
D * \\
0.63 \\
0.70\end{array}$ & 0.752 & $0 \cdot 106$ & 4 & $\begin{array}{l}169 \\
170 \\
171 \\
172 \\
173 \\
194\end{array}$ & $\begin{array}{c}1.02 \\
D * \\
0.57 \\
0.87 \\
0.63 \\
0.56\end{array}$ & 0.730 & $0 \cdot 256$ \\
\hline 5 & $\begin{array}{l}145 \\
146 \\
147 \\
148 \\
149\end{array}$ & $\begin{array}{l}2,680 \\
2,750 \\
2,330 \\
2,700 \\
2,840\end{array}$ & $\begin{array}{l}0.66 \\
0.80 \\
0.98 \\
0.85 \\
1.07\end{array}$ & 0.872 & $0 \cdot 197$ & 5 & $\begin{array}{l}145 \\
146 \\
147 \\
148 \\
149\end{array}$ & $\begin{array}{l}0.60 \\
0.95 \\
1.04 \\
0.70 \\
1.04\end{array}$ & 0.866 & 0.253 \\
\hline 7 & $\begin{array}{l}135 \\
136 \\
137 \\
138 \\
139\end{array}$ & $\begin{array}{l}2,150 \\
3,390 \\
2,260 \\
3,360 \\
2,780\end{array}$ & $\begin{array}{l}0.54 \\
0.88 \\
0.89 \\
1 \cdot 10 \\
0.71\end{array}$ & 0.824 & $0 \cdot 261$ & 7 & $\begin{array}{l}135 \\
136 \\
137 \\
138 \\
139\end{array}$ & $\begin{array}{l}0.77 \dagger \\
0.52 \\
0.70 \\
0.64 \\
0.70\end{array}$ & 0.666 & $0 \cdot 117$ \\
\hline 10 & $\begin{array}{l}161 \\
162 \\
186 \\
187 \\
188\end{array}$ & $\begin{array}{l}3,120 \\
2,400 \\
2,800 \\
3,330 \\
4,250\end{array}$ & $\begin{array}{l}1.02 \\
0.71 \\
1.18 \\
1.16 \\
0.75\end{array}$ & 0.964 & $0 \cdot 278$ & 10 & $\begin{array}{l}161 \\
162 \\
186 \\
187 \\
188\end{array}$ & $\begin{array}{l}1.20 \\
0.50 \\
1.53 \\
1.36 \\
1.46\end{array}$ & $1 \cdot 210$ & 0.517 \\
\hline 14 & $\begin{array}{l}180 \\
189 \\
190 \\
191 \\
193\end{array}$ & $\begin{array}{l}2,750 \\
2,760 \\
2,530 \\
2,630 \\
4,200\end{array}$ & $\begin{array}{l}0.90 \\
1 \cdot 12 \\
1.00 \\
1 \cdot 34 \\
1.01\end{array}$ & 1.074 & 0.209 & 14 & $\begin{array}{l}180 \\
189 \\
190 \\
191 \\
193\end{array}$ & $\begin{array}{l}1 \cdot 07 \\
1 \cdot 21 \\
1 \cdot 10 \\
1 \cdot 36 \\
1 \cdot 36\end{array}$ & $1 \cdot 220$ & $0 \cdot 172$ \\
\hline 21 & $\begin{array}{l}140 \\
141 \\
142 \\
143 \\
144\end{array}$ & $\begin{array}{l}2,580 \\
3,030 \\
2,920 \\
2,770 \\
2,150\end{array}$ & $\begin{array}{l}0.85 \\
0.74 \\
0.86 \\
1.41 \dagger \\
0.73\end{array}$ & 0.918 & $0 \cdot 350$ & 21 & $\begin{array}{l}140 \\
141 \\
142 \\
143 \\
144\end{array}$ & $\begin{array}{l}0.63 \dagger \\
0.56 \\
1.27 \\
0.82 \dagger \\
0.73 \dagger\end{array}$ & 0.802 & $0 \cdot 348$ \\
\hline 28 & $\begin{array}{l}153 \\
154 \\
155 \\
156 \\
157 \\
163\end{array}$ & $\begin{array}{l}2,450 \\
2,640 \\
2,960 \\
3,290 \\
2,480 \\
3,220\end{array}$ & $\begin{array}{l}0.83 \dagger \\
1.38 \\
1.10 \dagger \\
1.54 \\
0.86 \\
0.67\end{array}$ & 1.063 & 0.357 & 28 & $\begin{array}{l}153 \\
154 \\
155 \\
156 \\
157 \\
163\end{array}$ & $\begin{array}{l}D^{*} \\
1 \cdot 12 \\
0 \cdot 76 \dagger \\
1.84 \\
0.78 \\
0.66\end{array}$ & $1 \cdot 032$ & 0.600 \\
\hline 56 & $\begin{array}{l}128 \\
129 \\
130 \\
131 \\
132\end{array}$ & $\begin{array}{l}2,140 \\
2,260 \\
2,450 \\
2,260 \\
2,550\end{array}$ & $\begin{array}{l}1.42 \\
0.98 \\
1.12 \\
1.30 \\
0.70\end{array}$ & $1 \cdot 104$ & 0.350 & 56 & $\begin{array}{l}128 \\
129 \\
130 \\
131 \\
132\end{array}$ & $\begin{array}{l}1 \cdot 84 \\
1.23 \\
1.08 \\
1.26 \\
1 \cdot 18 \dagger\end{array}$ & $1 \cdot 318$ & 0.373 \\
\hline 84 & $\begin{array}{l}101 \\
102 \\
103 \\
104 \\
105 \\
\end{array}$ & $\begin{array}{l}3,600 \\
2,430 \\
3,230 \\
2,830 \\
2,660 \\
\end{array}$ & $\begin{array}{l}1 \cdot 32 \\
0 \cdot 70 \\
1.26 \\
1.00 \\
1.48 \\
\end{array}$ & $1 \cdot 152$ & $0 \cdot 381$ & 84 & $\begin{array}{l}101 \\
102 \\
103 \\
104 \\
105 \\
\end{array}$ & $\begin{array}{l}1.80 \\
1.24 \\
1.55 \dagger \\
0.99 \\
1.44 \\
\end{array}$ & 1.404 & $0 \cdot 381$ \\
\hline
\end{tabular}

* Result discarded on the grounds explained in the text. † Result allowed after the specimen had slipped out of one of the grips. 
By the late 1930's the time was ripe for a revival of the argument on the relative merits of using catgut and silk sutures. Howes (1933) and Whipple (1933) found that there was less exudation at the site of the wound when silk sutures were used than when catgut were used. Localio, Casale, and Hinton (1943), in an extensive series of investigations, found that wounds sutured with non-absorbable sutures increased in strength earlier and at a faster rate than those sutured with catgut. This was confirmed by Fast, Nelson, and Dennis (1947). Later, Nelson and Dennis (1951) showed that there was an optimum size of suture and that the use of a thicker one did not increase the tensile strength of the wound. This time, however, they did not find any difference between the tensile strength of wounds sutured with silk or catgut.

The tensile strength of wounds has been measured in various ways. Howes and Harvey (1929) measured the force required to pull the edges of the wound apart on a Scott thread-testing machine. Wounds in the walls of hollow cavities, e.g., the stomach (Howes, 1933) and abdominal wall (Localio, Casale, and Hinton, 1943) have been disrupted by the injection of air and the strength of the wound recorded as the pressure required to burst open the cavity. Recently, the fibrous tissue deposited in wounds has been measured by chemical assay (Neuman and Logan, 1950). The results of this method confirm the validity of the concept of the tensile strength of a wound being a measure of the amount of fibrous tissue deposited (Dunphy and Udupa, 1955; Grillo, Watts, and Gross, 1958). In the present investigation, the tensile strength of the wounds was used as a measure of the amount of fibrous tissue laid down.

\section{Experimental Methods}

Adult rabbits were used for all the experiments and in each case the right inferior rectus muscle was recessed $4 \mathrm{~mm}$., and the right superior rectus muscle was resected $4 \mathrm{~mm}$., as described in a previous paper (Ingram, 1965). All the rabbits were fed on a standard diet containing 14.7 per cent. protein. The tests were carried out at the following daily intervals after operation: $0,1,2,3,4,5,7,10,14,21,28,56$, and 84 days. The tensile strength of the wounds could not be measured with the eyes in situ in the orbit (because of the danger of haemorrhages if the venous sinus is opened) and therefore the eyes were removed before the test. A minimum of 5 results was obtained for each wound on each post-operative day. Two series of experiments were carried out; in the first series, $3 / 0$ plain catgut sutures were used, and in the second series $2 / 0$ white silk sutures were used.

The tensile-strength tests were performed as follows. The eye was enucleated as soon as the rabbit had been killed. A rectangle of sclera and cornea, with the muscle attached at the site of the wound, was cut from the eye. The specimen was mounted in the clamps of the Scott thread-testing machine with laconite "cushions" separating the tissues from the metal clamps; the scleral end was placed in the fixed clamp and the muscle in the clamp on the moveable carriage. The machine works on the inclined plane principle-as the rail tilts, the carriage (of known weight) tends to slide down, thus increasing the tension applied to the specimen. When the specimen breaks the carriage falls to the dependent end of the rail, and the end-point is automatically recorded on a chart.

There is one feature of this method of testing which has not been mentioned before in medical papers-namely a tendency for one end of the specimen to slip out of the clamp. With the specimens used in this investigation it was technically impossible to eliminate this. 
At the same time, it was not always possible to be sure whether a true break had occurred a short way along the muscle (muscle necrosis extended as far as $3 \mathrm{~mm}$. behind the wound), or whether the muscle, squashed by the clamps, had slipped out of the grip. When synthetic fibres are strained it is known that up to 90 per cent. of their breaking strength, when measured by a second test, is unaffected (Booth, 1961). Therefore, in this investigation, if it was obvious that a slip had occurred, or if there was any doubt about it being truly broken more than $3 \mathrm{~mm}$. from the site of the wound, the specimen was re-tested. If the end-point of the first test was less than 90 per cent. of the end-point of the second test, the result of the latter was considered as valid. If, on the other hand, the result for the first test was more than 90 per cent. of the result for the second test, the result was not included in the series, and the operation and test were repeated (it is admitted that the value of 90 per cent. may be too high, but there is no precedent in animal tissues and, in fact, less than 10 per cent. of the results were included subject to this factor).

\section{Results}

The results (Tables I and II) are expressed as the strength of the wound that was actually recorded rather than as a percentage of a control, because there was considerable variation between the strength of the unoperated muscle-to-sclera junctions, and therefore no suitable control.

The breaking strength of the unoperated muscle-to-sclera junctions is given in Table III.

TABLE III

TENSILE STRENGTH OF UNOPERATED MUSCLE-TO-SCLERA JUNCTIONS

\begin{tabular}{c|c|c|c|c|c}
\hline Animal & $\begin{array}{c}\text { Weight } \\
\text { (g.) }\end{array}$ & $\begin{array}{c}\text { Right Superior } \\
\text { Rectus (lb.) }\end{array}$ & $\begin{array}{c}\text { Left Superior } \\
\text { Rectus (lb.) }\end{array}$ & $\begin{array}{c}\text { Right Inferior } \\
\text { Rectus (lb.) }\end{array}$ & $\begin{array}{c}\text { Left Inferior } \\
\text { Rectus (lb.) }\end{array}$ \\
\hline A & 2,400 & 0.92 & 0.78 & 1.18 & 0.89 \\
B & 2,600 & 1.27 & $1 \cdot 16$ & 1.29 & 1.13 \\
C & 2,375 & 1.09 & 1.06 & 0.70 & 1.13 \\
D & 2,330 & 0.92 & 0.72 & 1.25 & 0.72 \\
E & 2,210 & 1.75 & 1.68 & 0.80 & 0.92 \\
F & 2,610 & 1.28 & 1.06 & 1.06 & 1.00 \\
\hline Mean & 2,754 & 1.20 & 1.07 & & \\
\hline
\end{tabular}

Table IV is a record of the site where the wounds broke apart. It is seen that the weakest part of the wound is the junction of the suture and the muscle. Only once did the suture itself break, and on this occasion the knot came undone. The figures in this Table can be grouped together as follows:

Total number of wounds where the suture pulled out of the sclera: Recession, 14; resection, 11 .

Total number of wounds where the suture pulled out of the muscle: Recession, 46; resection, 49.

The site of the break could not be recorded in a number of instances because it was not possible to identify the suture as a separate entity in the wound. In these cases, the suture appeared to be encased in fibrous tissue, and the specimen may have broken apart adjacent to the area of the wound. 
TABLE IV

SITE AT WHICH THE MUSCLE-TO-SCLERA WOUND BROKE APART

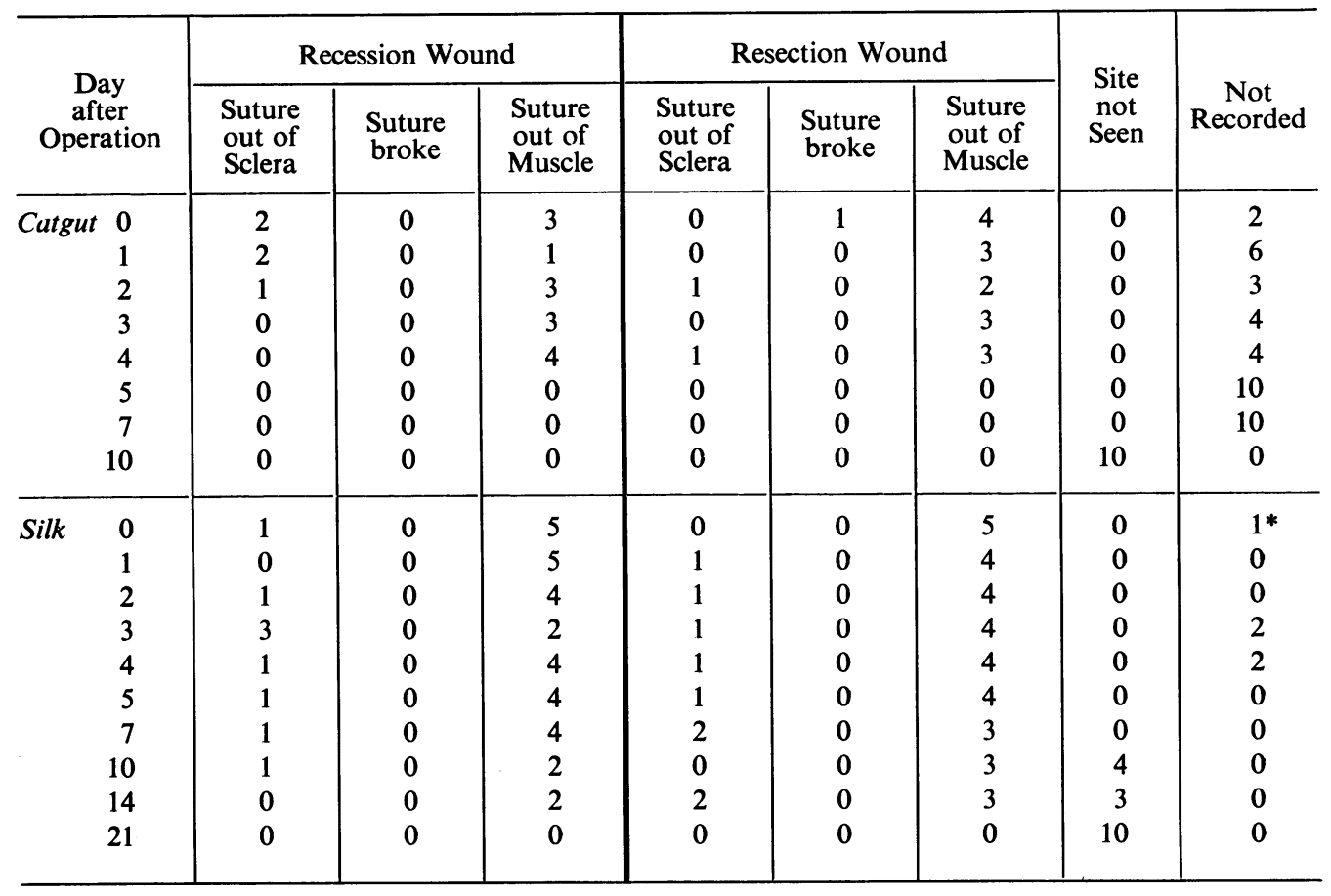

* In one case the suture was caught in one of the grips.

\section{Discussion}

It is quite clear that there is an appreciable variation between the results obtained for any one wound on any particular day. This is not surprising since there are many variable factors:

(1) The variation between any two animals, namely, their age, sex, state of , nutrition, and health.

(2) The size of the animals, and of their muscles, was variable.

(3) All the operations were carried out carefully, but it is not claimed that they all followed exactly the same course. The principle sources of variation were: (a) The amount of tissue damaged during the operation. (b) Variable bites of sclera were included in the sutures. (c) The hold of the suture for the muscle was probably variable, and it should be noted that the sutures were pulled out of the muscle in a direction which was parallel to the direction of the muscle fibres.

(4) Although enucleation was carried out as carefully as possible one cannot exclude a variable amount of damage being inflicted on the wounds before they were tested.

(5) The errors involved in mounting the specimen in the clamps of the tensiometer and the performance of the test are probably minimal compared with those above.

(6) The efficiency with which the suture was knotted is not included as a variable factor because the knot was the weakest point in only one wound. 
In spite of all the variations, a fairly clear pattern has emerged. The notable features (Figs 2 and 3) are as follows:

(i) The general shape of the curves is similar to that produced by previous workers.

(ii) The curve for each wound rises more steeply when silk sutures are used than when catgut sutures are used. This difference is not statistically significant because small samples were used, but the "silk" wounds are fairly consistently stronger where the curves are rising.

(iii) The strength of both wounds starts to rise 4 to 5 days after operation and reaches that of the normal unoperated muscle-to-sclera junction within 10 to 14 days.

(iv) Muscle becomes re-united with fibrous tissue at the same rate as it becomes re-united with muscle.

(v) There is a definite fall in the strength of both the wounds which were sutured with silk between the 14 th and 21 st days.

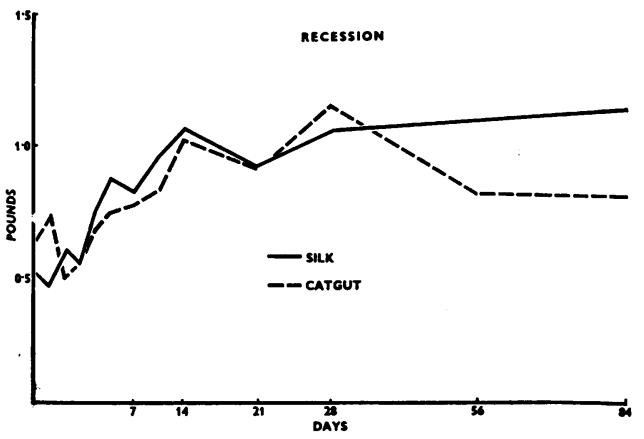

FiG. 2.-Graph showing results of tensile-strength tests on recession wounds.

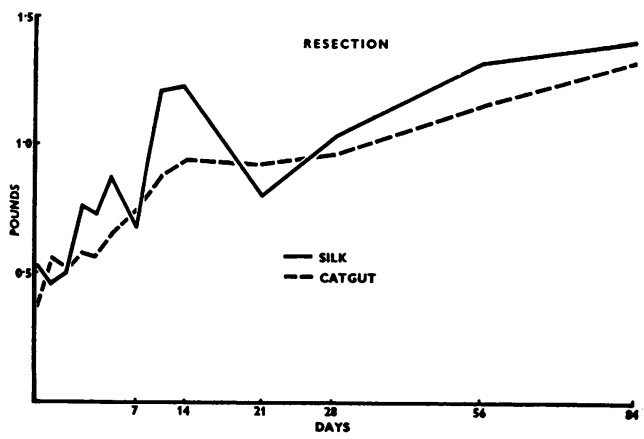

FIG. 3.-Graph showing results of tensile-strength tests on resection wounds.

Before comparing the results of these experiments with those of other workers, it is necessary to consider what factors contribute to the strength of a wound during the period of healing. Initially, there are only two factors, namely, the strength of the knotted, wet suture, and the ability of the tissues to retain the suture-a factor which will be called the "tear-away" strength. After a lag period, the strength of the wound increases because of the laying down of fibrous tissue. We do not know how the tear-away strength varies during this time, but the strength of the suture decreases at a rate which varies with the nature of the material.

If we look at the results for the wounds sutured with catgut it is evident that, at the time of operation, the tear-away strength is the limiting factor, because the strength of the suture is several times the recorded breaking strength of the wound and because, with one exception, the suture was never seen to break. This state of affairs continues until the strength of the wound increases from the deposition of the fibrous tissue. As the fibrous tissue is laid down mainly around the suture, we can regard the factor for the tear-away strength as being inseparable from the strength which the fibrous tissue gives to the wound. Therefore, after the curve has started to rise, the two factors which have to be considered are: (i) The amount of fibrous tissue deposited, and (ii) the strength of the suture.

As the latter drops below $0.5 \mathrm{lb}$. (i.e., less than the initial tear-away strength) and down to nil sometime between the 5th and 21st days (Lawrie, Angus, and Reese, 18 
1959), it can be assumed that its contribution towards the recorded breaking strength decreases accordingly. If allowance is made for this, a curve could be postulated which would represent the amount of fibrous tissue laid down day by day in the "catgut" wounds.

The results for the wounds sutured with silk can be interpreted on the same reasoning, the only difference being that silk sutures do not decrease in strength as quickly as do catgut ones. Nelson and Dennis (1951) found that silk sutures probably contribute nothing to the strength of the wound after 14 days. Postlethwait, Dillon, and Reeves, (1962) found that the strength of silk sutures was maintained for 14 days but thereafter it was variable.

The interesting feature of both the "silk" curves is the drop between the 14th and 21 st days, when the strength of the wounds falls to slightly less than that of the "catgut" wounds. By this time, the catgut suture does not contribute to the strength of the wound, and as a similar amount of fibrous tissue appears to have been deposited in both wounds 21 days after operation (Ingram, 1965), it is reasonable to postulate that the fibrous tissue is the only major factor contributing to the strength of both wounds. The recorded decrease in the strength of the "silk" wounds could therefore be explained by an equivalent decrease in the contribution of the silk sutures to the strength of the wound.

The extra strength imparted to the wounds by the silk suture between the 5 th and 14th days could also explain why the "silk" curves rise more steeply than the "catgut" curves. This explanation would also fit in with the histological observation that there appears to be no difference between the amount of fibrous tissue laid down in the wounds sutured with catgut and those sutured with silk during this period.

It will be seen from Table $\mathrm{V}$ that a wide variety of sutures is used for these operations in human subjects. The figures in this Table have been compiled from 142 replies to a questionnaire sent to ophthalmologists in the United Kingdom in 1960. The discrepancy between the total of 159 replies in the Table and the total of 142 replies received is due to the fact that 17 surgeons used a different suture for different operations. Catgut is the most popular material, but it is interesting to note the different sizes of suture that are used.

Table VI lists the type of knot used for tying the muscle suture

When a surgeon chooses between catgut and one of the relatively non-absorbable sutures, he must consider many factors; for example, the incidence of infection, the fact that silk and nylon sutures are sometimes extruded months after operation, allergic reactions to catgut, the varying degrees of inflammatory reaction caused by the suture, reliability of knots, and ease of handling. Nevertheless, the primary function of the suture is to hold the muscle to the sclera. It is not there to provoke an inflammatory reaction, and since the inflammatory reaction in these wounds after the second post-operative day appears to be proportional to the amount of suture material in the wound, it is reasonable to use as fine a strand of suture as it is safe to use. The suture must hold the muscle to the sclera until such time as enough fibrous tissue has been formed to do this, and during this period the wounds are subjected to varying strains. Madroszkiewicz's (1954) finding that the maximum pull of an extra-ocular muscle in man is $75 \mathrm{~g}$. $(0 \cdot 16 \mathrm{lb}$.) assumes considerable importance in this problem. 
TABLE V

SUTURES USED TO FASTEN THE MUSCLE TO THE SCLERA

\begin{tabular}{c|c|c}
\hline Material & Size & No. of Replies \\
\hline Catgut & Not given & 23 \\
& $3 / 0$ & 26 \\
& $4 / 0$ & 27 \\
& $5 / 0$ & 1 \\
& $6 / 0$ & 4 \\
\hline Silk & Not given & 27 \\
& No. 1 & 6 \\
& 0 & 7 \\
& $2 / 0$ & 6 \\
& $3 / 0$ & 6 \\
& $4 / 0$ & 4 \\
& $5 / 0$ & 2 \\
\hline Nylon & $6 / 0$ & 6 \\
\hline Mersilene & - & 2 \\
\hline Supramid & - & 2 \\
\hline
\end{tabular}

TABLE VI

TYPE OF KNOT USED FOR TYING THE MUSCLE SUTURE

\begin{tabular}{|c|}
\hline $\begin{array}{l}\text { Not stated } \\
\text { Reef knot } \\
\text { Surgeon's knot } \\
\text { Triple-throw knot }\end{array}$ \\
\hline Total \\
\hline
\end{tabular}

11 surgeons used one type of knot for a recession and a stronger knot for a resection.

It is pertinent, therefore, to consider what are the requirements of the suture in this situation. Initially, the tear-away strength is the weakest point in the wound, and neither this nor the strength of the suture should fall below a certain level before the tensile strength, measured with the suture in situ, starts to rise. This cannot be measured in man, and since the tissues involved are different in rabbits and in man, it will be necessary to carry out further experiments in monkeys. Nevertheless, we can deduce something from these experiments in rabbits because the tear-away strength for these wounds is similar to that found by Foster, Pemberton, and Freedman (1942), who inserted sutures into the sclera and muscles of human eyes being enucleated for various reasons. Furthermore, it is probable that the rate of deposition of fibrous tissue is roughly the same in man and in rabbits. 
Only once was the strength of one of these wounds less than the maximum pull of an extra-ocular muscle in man $(0 \cdot 16 \mathrm{lb}$.) and this was the one occasion when the knot came undone. It seems reasonable, therefore, to accept as the minimum "safe" mean strength of one of these wounds in man, $0.42 \mathrm{lb}$. (i.e., three times the maximum pull of an extra-ocular muscle). If catgut sutures are used the critical factor is that the strength of the suture itself should not fall below this level on the 5th day. Size $3 / 0$ is, therefore, quite adequate, and further experiments may well show that $4 / 0$ is large enough. On the other hand, the strength of the silk sutures probably does not alter during the first ten days and the tear-away strength is probably the limiting factor. The initial strength of a knotted, wet strand of silk suture need not, therefore, be as strong as that for catgut, and it is probably unnecessary to use sizes larger than 4/0. Similar arguments can be applied to the use of chromic catgut sutures, and according to the figures of Lawrie and others (1959) $5 / 0$ should be adequate.

One final clinical application of measurements of the strength of wounds in squint operations must be mentioned. Many surgeons still cover both eyes in a child for one or more days after operation. So far as I am aware no wound starts to increase in strength before the 4 th post-operative day. This means that if it is considered necessary to immobilize the eyes by double-padding in order to prevent the muscle being pulled off the sclera, it must be continued at least until the 4th day. It should however, be possible to select a suitable suture to render this practice superfluous.

\section{Summary}

(1) The rate at which the rabbit extra-ocular muscles become re-attached to the sclera after the operations of recession and resection has been measured by means of tensile-strength tests.

(2) These tests show that muscle becomes re-united with fibrous tissue at the same rate as muscle-to-muscle wounds heal. The strength of both these wounds attained that of the normal unoperated muscle-to-sclera junction 10 to 14 days after operation, irrespective of whether catgut or silk sutures were used.

(3) The wounds sutured with silk were consistently stronger than those sutured with catgut between 4 and 14 days after operation. This difference was not, however, statistically significant because small samples were used.

(4) There is no evidence to show that fibrous tissue is laid down earlier, or at a faster rate, when silk sutures are used than when catgut sutures are used. It is suggested that the increased strength of the "silk" wounds is due to the silk suture contributing more to the strength of the wound between the 4th and 14th days than the catgut suture does over the same period.

(5) The significance of the measurement of the strength of these wounds in rabbits and its relation to the size and nature of the sutures that should be used in these operations in man is discussed.

I wish to thank Mr. O. M. Duthie and Professor A. C. P. Campbell for their advice and support throughout the whole of this work.

The operations were carried out in the Department of Pathology at Manchester University and I wish to thank all their staff for their help and, in particular, Mr. H. Purvis for his skill in anaesthetizing the animals. 
It would have been impossible to carry out the tensile-strength tests but for the generosity of the Cotton, Silk, and Man-made Fibres Research Association (the Shirley Institute) in allowing me to use their Scott thread-testing machine without charge. I am also indebted to Miss M. G. Anderson for her help in the selection and use of the tensiometer.

Finally, I wish to thank the Research Grants Committee of the United Manchester Hospitals for providing the financial resources for this work.

\section{REFERENCES}

Booth, J. E. (1961). " "Principles of Textile Testing", Ch. 8. National Trade Press, London.

Carrel, A. (1910). J. Amer. med. Ass., 55, 2148.

Douglas, D. M. (1952). Brit. J. Surg., 40, 79.

DunPhy, J. E. (1960). Ann. roy. Coll. Surg. Engl., 26, 69. and Udupa, K. N. (1955). New. Engl. J. Med., 253, 847.

Fast, J., Nelson, C., and DenNis, C. (1947). Surg. Gynec. Obstet., 84, 685.

Foster, J., Pemberton, E. C., and Freedman, S. S. (1942). Trans. ophthal. Soc. U.K., 62, 320.

Gliedman, M. L., and Karlson, K. E. (1955). Amer. J. Ophthal., 39, 859.

Grillo, H. C., Watts, G. T., and Gross, J. (1958). Ann. Surg., 148, 153.

Hess, O. W. (1953). Surg. Gynec. Obstet., 96, 584.

Howes, E. L. (1933). I Ibid., 57, 309.

and Harvey, S. C. (1929). New Engl. J. Med., 200, 1285.

INGRAM, R. M. (1965). Brit. J. Ophthal., 49, 18.

LaWrie, P., ANgus, G. E., and Reese, A. J. M. (1959). Brit. J. Surg., 46, 638.

Localio, S. A., Casale, W., and Hinton, J. W. (1943). Surg. Gynec. Obstet., 77, $243,376$.

MADRosZKIEWICZ, M. (1954). Klin. oczna, 24, 255.

Mason, M. L., and Allen, H. S. (1941). Ann. Surg., 113, 424.

Nelson, C. A., and Dennis, C..(1951). Surg. Gynec. Obstet., 93, 461.

Neuman, R. E., and Logan, M. A. (1950). J. Biol. Chem., 186, 549.

Postlethwait, R. W., Dillon, M. L., and Reeves, J. W. (1962). Arch. Surg., 84, 698.

Whipple, A. O. (1933). Ann. Surg., 98, 662. 